\title{
Letter transpositions within and across morphemic boundaries: Is there a cross-language difference?
}

\author{
Claudia Sánchez-Gutiérrez • Kathleen Rastle
}

Published online: 30 March 2013

(C) Psychonomic Society, Inc. 2013

\begin{abstract}
Research on the impact of letter transpositions that arise across morpheme boundaries has yielded conflicting results. These results have led to the suggestion that a crosslinguistic difference may exist in the recognition of Spanish and English words. In two masked-priming experiments run on separate groups of Spanish and English speakers, we tested this hypothesis by comparing the impacts of primes with letter transpositions that arose within morphemes or across morpheme boundaries on the recognition of identical or nearidentical Spanish-English cognate targets. The results showed transposed-letter benefits in both Spanish and English that were not modulated by the position of the transposed letter in the prime stimulus. Our findings therefore add to the growing body of literature suggesting that the transposed-letter benefit is not affected by the position of the transposed letters relative to the morpheme boundary, and they dispel previous suggestions that there might be a genuine difference in orthographic coding across the Spanish and English writing systems.
\end{abstract}

Keywords Visual word recognition · Orthography · Masked priming

The recognition of a printed word such as pot requires the analysis of letter identity $(p, o, t)$ as well as of letter order (that the $p$ goes before both the $o$ and the $t$ ). In the absence of an analysis of letter order in the word recognition process, readers would be unable to detect the difference between anagram stimuli such as pot, opt, and top, which share the same letters, but in different configurations. Yet, despite the importance of letter order for disambiguating similar words, recent research has shown that letter position coding is surprisingly imprecise (see Davis, 2005; Grainger, 2008).

C. Sánchez-Gutiérrez

University of Salamanca, Salamanca, Spain

K. Rastle $(\bowtie)$

Department of Psychology, Royal Holloway University of

London, Egham, Surrey TW20 0EX, UK

e-mail: kathy.rastle@rhul.ac.uk
Some of the key phenomena in this respect concern the recognition of printed stimuli with transposed letters, such as waht. Despite the transposition of letters in this stimulus, research has shown that it is perceived as being very similar to its base word, what. Using a masked-priming technique, Forster, Davis, Schoknecht, and Carter (1987) established that identity primes (e.g., what-WHAT) and transposed-letter primes (e.g., waht-WHAT) yielded equivalent facilitation on word recognition, and further, that both of these types of primes yielded more facilitation than did replaced-letter primes (e.g., wrut-WHAT). This basic finding has now been observed across a number of the world's languages (e.g., Lee \& Taft, 2009; Perea \& Lupker 2004; Schoonbaert \& Grainger, 2004).

The transposed-letter benefit observed in masked priming (i.e., primes with transposed letters are more effective than those with replaced letters) has been interpreted as reflecting a degree of perceptual uncertainty in the coding of letter position (e.g., Davis, 2010; Gomez, Ratcliff, \& Perea, 2008). Yet, there may be limits to readers' tolerance for imprecision in letter order during word recognition. For example, research has suggested that tolerance for letter transpositions is reduced when the transpositions occur in external, as opposed to internal, positions (e.g., judeg-JUDGE vs. jugde-JUDGE; Johnson, Perea, \& Rayner, 2007). The study of these limits of the transposed-letter benefit is important because it gives rise to a deeper understanding of the abstract representations at the foundation of reading.

One key controversy in this area concerns the impact of letter transpositions when they occur at a morpheme boundary (e.g., urneal for unreal). Christianson, Johnson, and Rayner (2005) investigated readers' tolerance for these kinds of transpositions in a series of reading-aloud experiments using masked priming. In their third experiment, they compared the effects of letter transpositions on morphologically complex targets (e.g., BOASTER) and morphologically simple targets (e.g., BLUSTER, as blust is not a morpheme in English). The primes were identical to the targets (e.g., boaster, bluster), had a transposed letter at the morpheme boundary (e.g., boasetr, blusetr), or had a letter substitution (e.g., 
boasler, blusler). Simple-effects comparisons revealed different patterns of priming effects across the two sets of targets: While identity primes yielded facilitation in both conditions, transposed-letter primes facilitated recognition only for the morphologically simple targets, appearing to indicate that readers' tolerance for letter transpositions is reduced if the transpositions arise across a morpheme boundary. However, the critical interaction between target type (morphologically complex vs. morphologically simple) and prime condition (identity, transposition, or substitution) did not approach significance, indicating an unacceptably high probability that the numerical trends reported may have arisen by chance. Furthermore, though similar patterns of data were evident in the other two experiments that they reported (both of which used compound targets-e.g., sunshine, silkworm), similar difficulties over statistical reliability were also present.

Duñabeitia, Perea, and Carreiras (2007) sought to address the limitations of Christianson et al. (2005) in a series of three experiments conducted in Basque and Spanish. In both of the first two experiments, the authors contrasted masked-priming effects on morphologically complex versus morphologically simple targets. The primes for morphologically complex targets had a transposed or substituted letter across the morpheme boundary (e.g., mesoenro-MESONERO vs. mesoasro-MESONERO). The primes for morphologically simple targets had a transposed or substituted letter in the same location as in primes for the morphologically complex targets (e.g., escobmro-ESCOMBRO vs. escohcroESCOMBRO). The results in both experiments showed an interaction between target type and prime type, such that transposed-letter primes yielded facilitation on target recognition (relative to substitution primes) only for morphologically simple targets. The transposed-letter benefit vanished when the targets were morphologically complex words. Both of these initial experiments involved between-target comparisons, in which any number of uncontrolled differences could have existed across the sets of targets. Thus, in a third, more compelling experiment, conducted in Spanish, the authors examined the transposed-letter priming effect on recognition of a single set of morphologically complex targets, when the letter transpositions fell within the stem or across the morpheme boundary. These results revealed a significant 21-ms benefit for transposed-letter primes (relative to letter substitution primes) when the transposition fell within the morpheme, but no benefit ( $-1 \mathrm{~ms}$ ) when the transposition fell across the morpheme boundary, although this interaction between prime type and transposed-letter condition missed significance in the analysis by items $(p<.11)$.

The latter study on Spanish word recognition seems to indicate that orthographic coding demands sufficient precision to identify morphemic units, perhaps in order to facilitate the morphemic segmentation processes thought to characterize the initial stages of visual word recognition (e.g., Rastle,
Davis, \& New, 2004; see Rastle \& Davis, 2008, for a review). However, subsequent investigations in English have failed to replicate these findings (Beyersmann, Coltheart, \& Castles, 2012; Beyersmann, McCormick, \& Rastle, 2013; Rueckl \& Rimzhim, 2011). In particular, Rueckl and Rimzhim reported five masked-priming experiments in which they demonstrated persuasively that (a) the processing of a target word is facilitated by the prior presentation of a masked prime with two letters transposed; (b) this facilitation is observed even in cases in which the transposed letters straddle a morpheme boundary; and (c) this facilitation is equivalent when the transposed letters arise within a stem or across a morpheme boundary.

The strength of the findings reported by Duñabeitia et al. (2007) against all of the subsequent literature investigating English has led to the suggestion that important linguistic differences between Spanish and English might account for the discrepant results (Beyersmann et al., 2012; Beyersmann et al., 2013). The work of Velan and Frost (2009) on Hebrew word recognition has persuasively shown that letter transpositions can have very different effects on the recognition of words in languages with qualitatively different morphological characteristics. While Spanish and English have a similar morphological structure, Beyersmann et al. (2012) argued that Spanish is characterized by far greater morphological diversity and productivity than English. They pointed out that unlike English, Spanish morphology is used to express diminutives, augmentatives, pejoratives, and gender-related information (Beyersmann et al., 2012). In light of these differences, it is not unlikely that precision in the orthographic coding of the morphemic boundary may be more important in Spanish than it is in English.

Accordingly, we conducted a masked-priming study in which we investigated the effects of within-morpheme and across-morpheme letter transpositions on word recognition in groups using the Spanish and English languages. In order to avoid the difficulties associated with between-target comparisons, we selected Spanish-English cognates that were identical (e.g., ANTISOCIAL-ANTISOCIAL) or near identical (e.g., INCORRECT-INCORRECTO) as targets. The use of cognates ensured that there could be no idiosyncratic differences in the target stimuli across languages, and critically, also allowed us to perform identical manipulations to the stimuli across language groups when creating the transposed-letter primes. This very tight control over the stimulus characteristics across languages was vital in addressing our central question of whether the languages differ in their sensitivity to letter transpositions within morphemes and across morpheme boundaries. Because of difficulties related to statistical robustness in some of the key previous work, we used a much larger sample than in those studies (cf. Christianson et al., 2005, Exp. 3, $N=27$; Duñabeitia et al., 2007, Exp. 3, $N=32$ ).

On the basis of previous findings (cf. Duñabeitia et al., 2007; Rueckl \& Rimzhim, 2011), our prediction was that the 
transposed-letter benefit should be apparent for both language groups when the letter transposition arises within a morpheme, but should vanish for the Spanish-language group when the letter transposition arises across a morpheme boundary.

\section{Method}

Participants

The participants in Experiment 1a were 63 students from the University of Salamanca, all of whom were native Spanish speakers. The participants in Experiment $1 \mathrm{~b}$ were 64 students from Royal Holloway, University of London, all of whom were native English speakers. None of the participants had any history of language or literacy impairment. The participants in Experiment 1a completed the experiment as part of a course requirement, while those in Experiment $1 \mathrm{~b}$ were paid $£ 5$ for their participation.

\section{Materials}

The targets were 88 Spanish-English cognates matched very closely on $\log$ frequency (Spanish 0.70, English $0.69 ; t<1$ ), length (Spanish 9.18, English 8.99; $t=1.03$ ), and $N$ (Spanish 0.34 , English $0.35 ; t<1$ ). In order to secure sufficient numbers of Spanish-English cognate targets, we included both prefixed ( $N=44$; e.g., COOPERACIÓN-COOPERATION) and suffixed ( $N=44$; e.g., ACCESIBLE-ACCESSIBLE) words. We had no theoretical or empirical reason to expect that the nature of affixation would modulate the effects of interest (see also Duñabeitia et al., 2007), and we did not attempt to match the prefixed and suffixed sets.

For each target, two transposed-letter (TL) nonword primes were created by transposing adjacent letters, either within the stem (TL-within) or across the morpheme boundary (TL-across). These transpositions involved identical letters across the Spanish and English primes (e.g., TLacross: atléitco, athleitc; TL-within: atéltico, atheltic) in $97 \%$ of the cases. Two replaced-letter (RL) nonword primes were also created for each target by substituting other letters for the transposed letters, either within the stem (RL-within) or across the morpheme boundary (RL-across). RL primes were created by substituting vowels for vowels, consonants for consonants, ascending letters for ascending letters, and descending letters for descending letters, as far as possible in an identical manner across the languages. No transpositions involved the target's initial or final letter, and TL-within transpositions never involved the stem's initial or final letter. In all, $67 \%$ of the transpositions in the TL-across condition and $74 \%$ of the transpositions in the TL-within condition involved a consonant and a vowel. All prime stimuli are included in the Appendix.
Eighty-eight English-Spanish cognate nonwords were also designed to serve as the "No" responses. These nonwords all appeared morphologically complex and mirrored the word stimuli (half prefixed-e.g., ANTITOLM-ANTITOLMOand half suffixed-e.g., FROMOLISM-FROMOLISMO).

The primes for the nonword targets were constructed in the same way as those for the word targets.

The assignment of primes to targets for each language version of the experiment was counterbalanced over four lists, such that each participant was exposed to all four priming conditions of the experiment but saw each target item only once.

\section{Procedure and apparatus}

Stimulus presentation and data recording were controlled by DMDX software (Forster \& Forster, 2003). Each trial of the experiment consisted of a forward mask of hash marks presented for $500 \mathrm{~ms}$, followed by a prime in lowercase, presented for four screen refreshes (because of a slight variation in refresh rates across the laboratories, this resulted in prime durations of $66 \mathrm{~ms}$ in Exp. 1a and $57 \mathrm{~ms}$ in Exp. 1b). ${ }^{1}$ This lowercase prime was then masked by presentation of an uppercase target that remained on screen until participants decided whether the item was or was not a word in Spanish (Exp. 1a) or in English (Exp. 1b). The stimuli were presented on CRT monitors, and responses were collected using the keyboard. The target stimuli were presented in a different randomized order for each participant and were preceded by 13 practice trials constructed in a similar fashion to those in the main experiment.

\section{Results}

Reaction times (RTs) for correct responses were cleaned to remove outliers. Two of the target items were removed from Experiment $1 \mathrm{~b}$ (COAUTHOR and COPILOT) because they yielded more than $40 \%$ errors. Data points greater than 2,000 ms were also removed from each experiment. This led to the exclusion of 30 data points in Experiment 1a ( $0.54 \%$ of the data) and 67 data points in Experiment $1 \mathrm{~b}$ (1.2\% of the data). Data from all participants were retained in both experiments.

The data in both experiments were analyzed by subjects and by items in three-factor analyses of variance (ANOVAs). Condition (TL or RL) and Position (within morpheme or across morphemes) were treated as repeated factors in both analyses. Affix Type (prefixed or suffixed) was also included in the analysis, as a repeated factor in the by-subjects analysis

\footnotetext{
${ }^{1}$ We do not believe that this slight difference is cause for concern. Rueckl and Rimzhim (2011) used prime durations between 48 and $80 \mathrm{~ms}$ and observed a consistent pattern, and the prime durations used here were very close to those used by Duñabeitia et al. (2007; 66 ms)
} 
and an unrepeated factor in the by-items analysis. List was treated as an unrepeated factor in both analyses. Our analyses focused on the effect of condition and its interaction with position across languages.

The latency analyses from Experiment 1a (Spanish) revealed a main effect of condition, in which responses to words preceded by TL primes were faster than those to words preceded by RL primes $\left[F_{1}(1,60)=18.87, M S E=5,855.82, p<.01\right.$; $\left.F_{2}(1,80)=24.71, M S E=2,933.85, p<.01\right]$. Critically, this main effect was not modulated by position $\left[F_{1}(1,60)<1 ; F_{2}(1\right.$, $80)<1$, and no three-way interaction emerged between condition, position, and affix type $\left[F_{1}(1,60)<1 ; F_{2}(1,80)<1\right]$. The accuracy analyses from Experiment 1 a revealed no significant effects of condition, nor any interactions between condition, position, and affix type (all $p \mathrm{~s}>.10$ ).

Like the Spanish data, the latency analyses from Experiment $1 b$ (English) revealed a main effect of condition, in which responses to words preceded by TL primes were faster than those to words preceded by RL primes $\left[F_{1}(1,60)=\right.$ 13.12, $M S E=3,507.56, p<.01 ; F_{2}(1,78)=6.82, M S E=$ $4,014.36, p<.02]$. Critically, this main effect was not modulated by position $\left[F_{1}(1,60)<1 ; F_{2}(1,78)<1\right]$, and no threeway interaction emerged between condition, position, and affix type $\left[F_{1}(1,60)=3.59, p=.06 ; F_{2}(1,78)=2.21, p=.14\right]$. The accuracy analyses from Experiment $1 \mathrm{~b}$ revealed no significant effects of condition, nor any interactions between condition, position, and affix type (all $p \mathrm{~s}>.18$ ).

The RT and error data for both experiments are shown in Table 1 . We display the critical Condition $\times$ Position contrast broken down by affix types for interest, although it is important to remember that we did not attempt to match the prefixed and suffixed targets.

\section{Discussion}

Recent studies of the transposed-letter benefit have provided evidence central to our understanding of the basic processes underlying the early stages of visual word recognition. The purpose of this study was to investigate the transposed-letter benefit in the context of the recognition of morphologically complex words. Specifically, we wished to investigate the impact of letter transpositions when they arise within morphemes or across morpheme boundaries. This is an issue that has seen considerable controversy in recent years, with some studies reporting a reduction in the transposed-letter benefit when letter transpositions arise across morpheme boundaries (e.g., Duñabeitia et al., 2007), and others reporting no difference in the magnitudes of the transposed-letter benefit as a function of the position of the transposed letter (e.g., Beyersmann et al., 2012; Beyersmann et al., 2013; Rueckl \& Rimzhim, 2011). Critically, Duñabeitia et al. conducted their most compelling study in Spanish, while the other statistically reliable studies have used English stimuli, leading to speculation that there might be a cross-linguistic difference in orthographic coding (Beyersmann et al., 2012).

In order to assess this hypothesis, we created parallel Spanish and English experiments, using Spanish-English cognate stimuli matched very closely across languages (e.g., IDEALISTA-IDEALIST; ACCIDENTAL-ACCIDENTAL). These target stimuli were preceded by masked primes containing transposed letters within the stem morphemes or across morpheme boundaries, and the transposed-letter benefit was calculated relative to a replaced-letter priming condition in which letters were replaced within the stem morphemes or across morpheme boundaries. By using Spanish-English cognate stimuli that were identical or virtually identical, we ensured that any differences observed across our Spanish and English experiments could not be attributed to idiosyncratic aspects of the items chosen, and instead would need to be attributed to a genuine cross-linguistic difference in orthographic coding.

The results were unambiguous in showing transposed-letter benefits in both Spanish and English that were not modulated by the position of the transposed letter in the prime stimulus. For both language versions of the experiment, the sizes of the transposed-letter benefit were equivalent when the transposed letter occurred within the stem and when it occurred across the morpheme boundary. These results are inconsistent

Table 1 Reaction times (in milliseconds) and percentages of errors (in parentheses) for Experiments 1a and 1b, shown by condition (transposedletter [TL] or replaced-letter [RL]), position (within or across morphemes), and affix type (prefixed or suffixed)

\begin{tabular}{|c|c|c|c|c|}
\hline \multirow[b]{2}{*}{ Position } & \multicolumn{2}{|c|}{ Experiment 1a (Spanish) } & \multicolumn{2}{|c|}{ Experiment 1b (English) } \\
\hline & $\mathrm{TL}$ & RL & $\mathrm{TL}$ & RL \\
\hline Across morphemes & $767(1.9 \%)$ & $799(1.9 \%)$ & $767(4.7 \%)$ & $785(5.8 \%)$ \\
\hline Suffixed & $734(1.4 \%)$ & $766(1.0 \%)$ & $732(3.5 \%)$ & $761(3.8 \%)$ \\
\hline Prefixed & $800(2.4 \%)$ & $831(2.8 \%)$ & $803(5.9 \%)$ & $810(7.8 \%)$ \\
\hline Within morphemes & $770(1.4 \%)$ & $797(2.3 \%)$ & $766(5.7 \%)$ & $787(5.6 \%)$ \\
\hline Suffixed & $754(1.1 \%)$ & $774(2.1 \%)$ & $754(5.5 \%)$ & $768(5.1 \%)$ \\
\hline Prefixed & $785(1.7 \%)$ & $820(2.5 \%)$ & $779(5.9 \%)$ & $806(6.0 \%)$ \\
\hline
\end{tabular}


with the findings reported by Duñabeitia et al. (2007), but are consistent with all of the statistically reliable English studies (Beyersmann et al., 2012; Beyersmann et al., 2013; Rueckl \& Rimzhim, 2011). Because our stimuli were so closely matched across language versions of the experiment, we can be assured that there is no difference between Spanish and English in the coding of orthographic information, as had seemed to be implied by the previous literature.

Our findings therefore add to the growing body of literature suggesting that the transposed-letter benefit is not affected by the position of the transposed letters relative to the morpheme boundary. The work of Duñabeitia et al. (2007) is a clear outlier in this body of literature. In light of our findings, we believe that the findings of Duñabeitia et al. reflected idiosyncratic properties of the stimuli or the participants, or a Type I error.

Author Note C.S.G. was the recipient of a postgraduate grant cofinanced by the European Social Fund and the Government of Castilla-y-León. K.R. was supported by a research grant from the Economic and Social Research Council (RES-062-23-2268). We are grateful to Sachiko Kinoshita and Jon Andoni Duñabeitia for helpful comments on a previous version of this article.

\section{Appendix}

\begin{tabular}{|c|c|c|c|c|}
\hline Target & TL-Across & TL-Within & RL-Across & RL-Within \\
\hline \multicolumn{5}{|c|}{ Spanish Stimuli } \\
\hline abundancia & abunadncia & abnudancia & abunotncia & abrodancia \\
\hline accesible & acceisble & acecsible & acceerble & acarsible \\
\hline accidental & accidenatl & acicdental & accidenefl & acerdental \\
\hline acrobático & acrobáitco & acorbático & acrobáelco & acasbático \\
\hline activar & actiavr & acitvar & actiozr & acelvar \\
\hline acusación & acuasción & aucsación & acuección & aorsación \\
\hline adaptable & adapatble & adpatable & adapilble & adjotable \\
\hline admirable & admiarble & amdirable & admiexble & artirable \\
\hline adopción & adocpión & aodpción & adorjión & aebpción \\
\hline alcohólico & alcohóilco & alochólico & alcohóetco & alashólico \\
\hline asistencia & asisetncia & assitencia & asisilncia & ascatencia \\
\hline atlético & atléitco & atéltico & atléofco & atoftico \\
\hline banquero & banqeuro & baqnuero & banqoaro & bagsuero \\
\hline clasicismo & clasiicsmo & claiscismo & clasiezsmo & claercismo \\
\hline comparable & compaarble & copmarable & compaecble & cojnarable \\
\hline confesión & confeisón & cofnesión & confeacón & cohresión \\
\hline contable & conatble & cnotable & conolble & cretable \\
\hline idealista & ideailsta & iedalista & ideaufsta & iotalista \\
\hline dictatorial & dictatoiral & ditcatorial & dictatoecal & dilsatorial \\
\hline editorial & editoiral & edtiorial & editousal & edhaorial \\
\hline evaluación & evalaución & evlauación & evaleoción & evtouación \\
\hline generación & genearción & geenración & geneosción & geasración \\
\hline heroísmo & heríosmo & hreoísmo & hereasmo & hsuoísmo \\
\hline imaginable & imagianble & imgainable & imagiorble & imjoinable \\
\hline legendario & legenadrio & legnedario & legenotrio & legrudario \\
\hline liberalismo & liberailsmo & libearlismo & liberaofsmo & libeoslismo \\
\hline limonada & limoanda & liomnada & limoerda & liesnada \\
\hline marginal & margianl & magrinal & margiorl & mapcinal \\
\hline miserable & misearble & miesrable & miseonble & miocrable \\
\hline molecular & molecualr & moelcular & molecuetr & moatcular \\
\hline oriental & orienatl & oreintal & orienofl & oroantal \\
\hline perversión & perverisón & pevrersión & perverecón & pensersión \\
\hline pintor & pinotr & pnitor & pinalr & prator \\
\hline
\end{tabular}




\begin{tabular}{|c|c|c|}
\hline racista & raicsta & rcaista \\
\hline razonable & razoanble & raoznable \\
\hline realismo & reailsmo & raelismo \\
\hline recital & reciatl & rceital \\
\hline simbolismo & simboilsmo & sibmolismo \\
\hline sintáctico & sintácitco & sitnáctico \\
\hline tropical & tropiacl & trpoical \\
\hline urgencia & urgecnia & uregncia \\
\hline verbal & verabl & vrebal \\
\hline vocacional & vocacioanl & voaccional \\
\hline invitación & inviatción & inivtación \\
\hline antisocial & antsiocial & antisoical \\
\hline antítesis & anttíesis & antíteiss \\
\hline biosfera & bisofera & biosfrea \\
\hline impersonal & ipmersonal & imperosnal \\
\hline coautor & caoutor & coatuor \\
\hline copiloto & cpoiloto & copiolto \\
\hline desconectar & decsonectar & descoenctar \\
\hline deshonesto & dehsonesto & deshonseto \\
\hline desilusión & deislusión & desilsuión \\
\hline desleal & delseal & deslael \\
\hline desorden & deosrden & desodren \\
\hline disparidad & dipsaridad & dispardiad \\
\hline impaciente & ipmaciente & impaceinte \\
\hline imperfecto & ipmerfecto & impefrecto \\
\hline imparcial & ipmarcial & impacrial \\
\hline impropio & ipmropio & improipo \\
\hline incoherente & icnoherente & incohreente \\
\hline incorrecto & icnorrecto & incorercto \\
\hline indecente & idnecente & indecnete \\
\hline indirecto & idnirecto & indirceto \\
\hline indiscreto & idniscreto & indisrceto \\
\hline informal & ifnormal & infomral \\
\hline inhumano & ihnumano & inhuamno \\
\hline injusticia & ijnusticia & injusitcia \\
\hline interacción & intearcción & interacicón \\
\hline invisible & ivnisible & inviisble \\
\hline prehistoria & prheistoria & prehitsoria \\
\hline prematuro & prmeaturo & premtauro \\
\hline presuponer & prseuponer & presupnoer \\
\hline reactivar & raectivar & reactviar \\
\hline reconstruir & rceonstruir & recontsruir \\
\hline reformado & rfeormado & refomrado \\
\hline regenerar & rgeenerar & regenrear \\
\hline rehabilitar & rheabilitar & rehaiblitar \\
\hline reproducir & rperoducir & reprdoucir \\
\hline reunir & ruenir & reuinr \\
\hline semifinal & semfiinal & semifnial \\
\hline semicírculo & semciírculo & semicíruclo \\
\hline subatómico & suabtómico & subatmóico \\
\hline subdividir & sudbividir & subdivdiir \\
\hline submarino & sumbarino & submairno \\
\hline
\end{tabular}

\begin{tabular}{|c|c|}
\hline raersta & rsoista \\
\hline razoerble & raesnable \\
\hline reaotsmo & roulismo \\
\hline reciefl & rsoital \\
\hline simboetsmo & sidvolismo \\
\hline sintácelco & silsáctico \\
\hline tropiorl & trgaical \\
\hline urgarnia & urapncia \\
\hline verodl & vsobal \\
\hline vocacioerl & voencional \\
\hline inviolción & inastación \\
\hline antraocial & antisoesal \\
\hline antfoesis & antíteacs \\
\hline bicafera & biosfcoa \\
\hline ignersonal & imperarnal \\
\hline ceiutor & coaleor \\
\hline cjeiloto & copiafto \\
\hline dervonectar & descoavctar \\
\hline detronesto & deshonruto \\
\hline deorlusión & desilcaión \\
\hline detceal & desluol \\
\hline deacrden & desotsen \\
\hline digraridad & disparbead \\
\hline iqnaciente & impacounte \\
\hline igrerfecto & impelsecto \\
\hline ijnarcial & impasnial \\
\hline igsropio & improajo \\
\hline irsoherente & incohnaente \\
\hline isrorrecto & incorascto \\
\hline itrecente & indecrite \\
\hline ifsirecto & indirsuto \\
\hline ilriscreto & indisnseto \\
\hline itsormal & infoncal \\
\hline ilrumano & inhuirno \\
\hline ipsusticia & injuselcia \\
\hline inteozcción & interacarón \\
\hline icrisible & invierble \\
\hline prloistoria & prehifroria \\
\hline prniaturo & premlouro \\
\hline prcauponer & presupraer \\
\hline ruoctivar & reactzoar \\
\hline rsaonstruir & reconlcruir \\
\hline rlaormado & refonsado \\
\hline rqoenerar & regensoar \\
\hline rfoabilitar & rehaedlitar \\
\hline rgaroducir & reprbaucir \\
\hline roanir & reuacr \\
\hline semloinal & semifroal \\
\hline semraírculo & semicíraslo \\
\hline suodtómico & subatneico \\
\hline sutlividir & subdivboir \\
\hline sundarino & submaesno \\
\hline
\end{tabular}


subnormal

supermercado

unilateral

English Stimuli

abundance

accessible

accidental

acrobatic

activate

accusation

adaptable

admirable

adoption

alcoholic

assistance

athletic

banker

classicism

comparable

confession

countable

idealist

dictatorial

editorial

evaluation

generation

heroism

imaginable

legendary

liberalism

lemonade

marginal

miserable

molecular

oriental

perversion

painter

racist

reasonable

realism

recital

symbolism

syntactic

tropical

urgency

verbal

vocational

invitation

antisocial

antithesis

biosphere

impersonal sunbormal

supemrercado

unliateral

abunadnce

accesisble

accidenatl

acrobaitc

actiavte

accuastion

adapatble

admiarble

adopiton

alcohoilc

assisatnce

athleitc

banekr

classiicsm

compaarble

confesison

counatble

ideailst

dictatoiral

editoiral

evalaution

geneartion

heriosm

imagianble

legenadry

liberailsm

limoande

margianl

misearble

molecualr

orienatl

perverison

painetr

raicst

reasoanble

reailsm

reciatl

symboilsm

syntacitc

tropiacl

urgecny

verabl

vocatioan1

inviattion

antsiocial

anttihesis

bisophere

ipmersonal subnomral

supermecrado

unilatreal

abnudance

acecssible

acicdental

acorbatic

acitvate

acucsation

adpatable

amdirable

aodption

alocholic

asssitance

atheltic

bnaker

clasiscism

copmarable

cofnession

conutable

iedalist

ditcatorial

edtiorial

evlauation

geenration

hreoism

imgainable

legnedary

libearlism

liomnade

magrinal

miesrable

moelcular

oreintal

pevrersion

paniter

rcaista

reaosnable

raelism

rceital

sybmolismo

sytnactic

trpoical

uregncy

vrebal

voactional

inivtation

antisoical

antitheiss

biosphree

imperosnal suvdormal

supensercado

unfeateral

abunotnce

acceserble

accidenefl

acrobaelc

actiozte

acuection

adapilble

admiexble

adorjion

alcohoetc

assisilnce

athleofc

banotr

classiezsm

compaecble

confesacon

counolble

ideaufst

dictatoecal

editousal

evaleotion

geneostion

hereasm

imagiorble

legenotry

liberaofsm

limoerde

margiorl

miseonble

molecuetr

orienofl

perverecon

painalr

raerst

reasoerble

reaotsm

reciefl

symboetsm

syntacelc

tropiorl

urgarny

verodl

vocatioerl

invioltion

anlriocial

antfohesis

bicaphere

ignersonal subnonsal

supermesnado

unilatcoal

abrodance

acarssible

acerdental

acasbatic

acelvate

acorsation

adjotable

artirable

aebption

alasholic

asscatance

athoftic

bruker

clasercism

cojnarable

cohression

coretable

iotalist

dilsatorial

edhaorial

evtouation

geasration

hsuoism

imjoinable

legrudary

libeoslism

liesnade

mapcinal

miocrable

moatcular

oroantal

pensersion

parator

rsoist

reaeznable

roulism

rsoital

sydvolism

sylsactic

trgaical

urepscy

vsobal

voentional

inastation

antisoesal

antitheacs

biosphcoe

imperarnal 


\begin{tabular}{|c|c|c|c|c|}
\hline coauthor & caouthor & coatuhor & ceiuthor & coalehor \\
\hline copilot & cpoilot & copiolt & cjeilot & copiaft \\
\hline disconnect & dicsonnect & disconenct & dervonnect & desconavet \\
\hline dishonest & dihsonest & dishonset & ditronest & dishonrut \\
\hline disillusion & diisllusion & disillsuion & diorllusion & desillcaion \\
\hline disloyal & dilsoyal & dislyoal & ditcoyal & disljel \\
\hline disorder & diosrder & disodrer & diacrder & disotser \\
\hline disparity & dipsarity & dispartiy & digrarity & disparbey \\
\hline impatient & ipmatient & impateint & iqnatient & impacount \\
\hline imperfect & ipmerfect & impefrect & igrerfect & impelsect \\
\hline impartial & ipmartial & impatrial & ijnartial & impasnial \\
\hline improper & ipmroper & improepr & igsroper & improajr \\
\hline incoherent & icnoherent & incohreent & irsoherent & incohnaent \\
\hline incorrect & icnorrect & incorerct & isrorrect & incorasct \\
\hline indecent & idnecent & indecnet & itrecent & indecrit \\
\hline indirect & idnirect & indircet & ifsirect & indirsut \\
\hline indiscreet & idniscreet & indisrceet & ilriscreet & indisnseet \\
\hline informal & ifnormal & infomral & itsormal & infoncal \\
\hline inhuman & ihnuman & inhuamn & ilruman & inhuirn \\
\hline injustice & ijnustice & injusitce & ipsustice & injuselce \\
\hline interaction & intearction & interaciton & inteozction & interacalon \\
\hline invisible & ivnisible & inviisble & icrisible & invierble \\
\hline prehistory & prheistory & prehitsory & pcleistory & prehifrory \\
\hline premature & prmeature & premtaure & psneature & premloure \\
\hline presuppose & prseuppose & presuppsoe & prcauppose & presupprae \\
\hline reactivate & raectivate & reactviate & ruoctivate & reactzoate \\
\hline reconstruct & rceonstruct & recontsruct & rsaonstruct & reconlcruct \\
\hline reformed & rfeormed & refomred & rlaormed & refonsed \\
\hline regenerate & rgeenerate & regenreate & rqoenerate & regensoate \\
\hline rehabilitate & rheabilitate & rehaiblitate & rfoabilitate & rehaedlitate \\
\hline reproduce & rperoduce & reprdouce & rgaroduce & reprbauce \\
\hline reunite & ruenite & reuinte & roanite & reuacte \\
\hline semifinal & semfiinal & semifnial & semloinal & semifroal \\
\hline semicircle & semciircle & semicricle & semraircle & semicsacle \\
\hline subatomic & suabtomic & subatmoic & suodtomic & subatneic \\
\hline subdivide & sudbivide & subdivdie & sutlivide & subdivboe \\
\hline submarine & sumbarine & submairne & sundarine & submaesne \\
\hline subnormal & sunbormal & subnomral & suvdormal & subnonsal \\
\hline supermarket & supemrarket & supermakret & supensarket & supermatset \\
\hline unilateral & unliateral & unilatreal & unfeateral & unilatcoal \\
\hline
\end{tabular}

\section{References}

Beyersmann, E., Coltheart, M., \& Castles, A. (2012). Parallel processing of whole words and morphemes in visual word recognition. Quarterly Journal of Experimental Psychology, 65, 1798-1819. doi:10.1080/17470218.2012.672437

Beyersmann, E., McCormick, S. F., \& Rastle, K. (2013). Letter transpositions within morphemes and across morpheme boundaries. Quarterly Journal of Experimental Psychology. doi:10.1080/17470218.2013.782326

Christianson, K., Johnson, R. L., \& Rayner, K. (2005). Letter transpositions within and across morphemes. Journal of Experimental
Psychology: Learning, Memory, and Cognition, 31, 1327-1339. doi:10.1037/0278-7393.31.6.1327

Davis, C. J. (2005). Orthographic input coding: A review of behavioural data and current models. In S. Andrews (Ed.), From inkmarks to ideas: Challenges and controversies about word recognition and reading. Hove, UK: Psychology Press.

Davis, C. J. (2010). The spatial coding model of visual word identification. Psychological Review, 117, 713-758. doi:10.1037/a0019738

Duñabeitia, J. A., Perea, M., \& Carreiras, M. (2007). Do transposedletter similarity effects occur at a morpheme level? Evidence for morpho-orthographic decomposition. Cognition, 105, 691-703. doi:10.1016/j.cognition.2006.12.001 
Forster, K. I., Davis, C., Schoknecht, C., \& Carter, R. (1987). Masked priming with graphemically related forms: Repetition or parallel activation? Quarterly Journal of Experimental Psychology, 39A, 211-251. doi:10.1080/14640748708401785

Forster, K. I., \& Forster, J. C. (2003). DMDX: A Windows display program with millisecond accuracy. Behavior Research Methods, Instruments, \& Computers, 35, 116-124. doi:10.3758/ BF03195503

Gomez, P., Ratcliff, R., \& Perea, M. (2008). The overlap model: A model of letter position coding. Psychological Review, 115, 577600. doi:10.1037/a0012667

Grainger, J. (2008). Cracking the orthographic code: An introduction. Language \& Cognitive Processes, 23, 1-35. doi:10.1080/ 01690960701578013

Johnson, R. L., Perea, M., \& Rayner, K. (2007). Transposed-letter effects in reading: Evidence from eye movements and parafoveal preview. Journal of Experimental Psychology. Human Perception and Performance, 33, 209-229. doi:10.1037/0096-1523.33.1.209

Lee, C. H., \& Taft, M. (2009). Are onsets and codas important in processing letter position? A comparison of TL effects in English and Korean. Journal of Memory and Language, 60, 530-542. doi:10.1016/j.jml.2009.01.002
Perea, M., \& Lupker, S. J. (2004). Can CANISO activate CASINO? Transposed-letter similarity effects with nonadjacent letter positions. Journal of Memory and Language, 51, 231-246. doi:10.1016/j.jml.2004.05.005

Rastle, K., \& Davis, M. H. (2008). Morphological decomposition based on the analysis of orthography. Language \& Cognitive Processes, 23, 942-971. doi:10.1080/01690960802069730

Rastle, K., Davis, M. H., \& New, B. (2004). The broth in my brother's brothel: Morpho-orthographic segmentation in visual word recognition. Psychonomic Bulletin and Review, 11, 1090-1098. doi:10.3758/BF03196742

Rueckl, J. G., \& Rimzhim, A. (2011). On the interaction of letter transpositions and morphemic boundaries. Language \& Cognitive Processes, 26, 482-508. doi:10.1080/01690965.2010.500020

Schoonbaert, S., \& Grainger, J. (2004). Letter position coding in printed word perception: Effects of repeated and transposed letters. Language \& Cognitive Processes, 19, 333-367. doi:10.1080/ 01690960344000198

Velan, H., \& Frost, R. (2009). Letter-transposition effects are not universal: The impact of transposing letters in Hebrew. Journal of Memory and Language, 61, 285-302. doi:10.1016/ j.jml.2009.05.003 